\title{
Contribution of Pueraria phaseoloides L. in the Cycling of Macronutrients in oil Palm Plantations
}

\author{
Ismael de Jesus Matos Viégas, Milton Garcia Costa, Eric Victor de Oliveira Ferreira, Nilda \\ Leonor Pezo Peréz, Henrique da Silva Barata, Jessivaldo Rodrigues Galvão, Heráclito \\ Eugenio Oliveira da Conceição, Sérgio Dias do Espírito Santo \\ Universidade Federal Rural da Amazônia, Brazil
}

Received: April 30, 2021 Accepted: May 27, $2021 \quad$ Published: May 30, 2021

doi:10.5296/jas.v9i3.18577～URL: https://doi.org/10.5296/jas.v9i3.18577

\begin{abstract}
The use of cover crops has become a common practice in oil palm plantations, ensuring greater sustainability to agroecosystems, increasing nutrient cycling and providing greater savings in the use of mineral fertilizers. In this sense, the objective of this study was to evaluate the accumulation of macronutrients (N, P, K, Ca, Mg and S) in tropical kudzu plants (Pueraria phaseoloides L.) in oil palm plantations. The experiment was carried out in the municipality of Tailândia, Pará State, using a completely randomized experimental design, four replications and seven treatments (ages of oil palm). The accumulation of macronutrients was obtained through the product of nutrient concentrations and the dry matter of the aerial part of the living, dead and total cover of tropical kudzu. The order of total accumulation of cycled nutrients by legumes was $\mathrm{Ca}, \mathrm{N}, \mathrm{K}, \mathrm{Mg}, \mathrm{P}$ and $\mathrm{S}$. Tropical kudzu cultivation, as a cover plant, contributes to nutrient cycling in oil palm plantations, but this benefit decreased with the age of palm oil trees.
\end{abstract}

Keywords: cover crops, legumes, nutritional diagnosis, oilseed, tropical kudzu

\section{Introduction}

Cover crops are important parts of sustainable agricultural systems in tropical regions. The use of cover crops produces several benefits; prevention of soil erosion, suppression of undesirable plants, improvement of microbial activity and soil quality, in addition to maintaining soil moisture (Fageria et al., 2014a). The cover crops produce a large amount of biomass and have a pivoting root system that can extract nutrients from deeper soil layers, making them available after decomposition (Favero et al., 2000).

The use of cover crops, mainly with tropical kudzu legumes (Pueraria phaseoloides L.), is common in the cultivation of palm trees, such as coconut palm (Lins and Viégas, 2020) and oil palm (Rodrigues et al., 2002; Viégas et al., 2019). For the conditions of Pará, there is the 
recommendation of the intercropped planting of tropical kudzu and the oil palm (Viégas and Botelho, 2007). Legumes are known for their ability to increase the amount of soil organic matter (SOM) and their fertility due to symbiosis with rhizobacteria, which provides the fixation of atmospheric nitrogen $\left(\mathrm{N}_{2}\right)$ and decreased fertilizer costs in commercial plantations (Hutasoit et al., 2017). In this sense, legumes become a possibility to increase the availability of $\mathrm{N}$ to oil palm (Agamuthu and Broughton, 1985), in addition to cycling other nutrients.

The intercropped cultivation of legumes and oil palm can change the dynamics of nutrient extraction and replacement in the agricultural ecosystem (Favero et al., 2000). The understanding of nutrient concentrations in cover crops provides a better understanding of the dynamics of these nutrients in ecosystems (Viégas et al., 2018), besides assisting in the nutritional management of the oil palm. In the conditions of cultivation of oil palm in Pará State, there are studies on the concentration of nutrients in tropical kudzu (Peréz and Viégas, 1997), but without the evaluation of their accumulation. For micronutrients, there is evaluation in Pueraria phaseoloides L. intercropped oil palm in Pará (Viégas et al., 2018).

On the other hand, to be successful in the use of cover crops, it is necessary that the selected species tolerates high soil acidity and to be efficient in the use of nutrients (Fageria et al., 2014a), mainly in oil palm plantations where the practice of liming is not common (Homma and Rebello, 2020) in acid soils of the Amazon (Franzini et al., 2017). The efficiency of the use of nutrients by cover crops is based on the ability to acquire, transport, and remobilize nutrients in their tissues (Baligar et al., 2001). The efficiency of nutrient use is influenced by the interaction of plants and environmental variables (solar radiation, temperature, and precipitation) and the interactions on legumes in tropical soils are limited (Fageria et al., 2014a), making it essential to study this theme in specific edaphoclimatic conditions.

In this sense, the objective of this work was to evaluate the accumulation of macronutrients in tropical kudzu plants intercropped with oil palm in northeastern Pará, Brazil.

\section{Method}

The study was carried out in Tailândia, region of Pará northeastern, Eastern Amazon, in the commercial oil palm plantations (hybrid Tenera) of the Royal Agroindustrial Company. The climate of the municipality is tropical rainy type without seasonal thermal variation, according to Köppen classification, with an average temperature of $26^{\circ} \mathrm{C}$, average relative humidity of $83 \%$ and annual precipitation of 2,400 $\mathrm{mm}$. During the conduction of the experiment, rainfall monitoring (Figure 1) of the research area was performed with the aid of a rain gauge. 


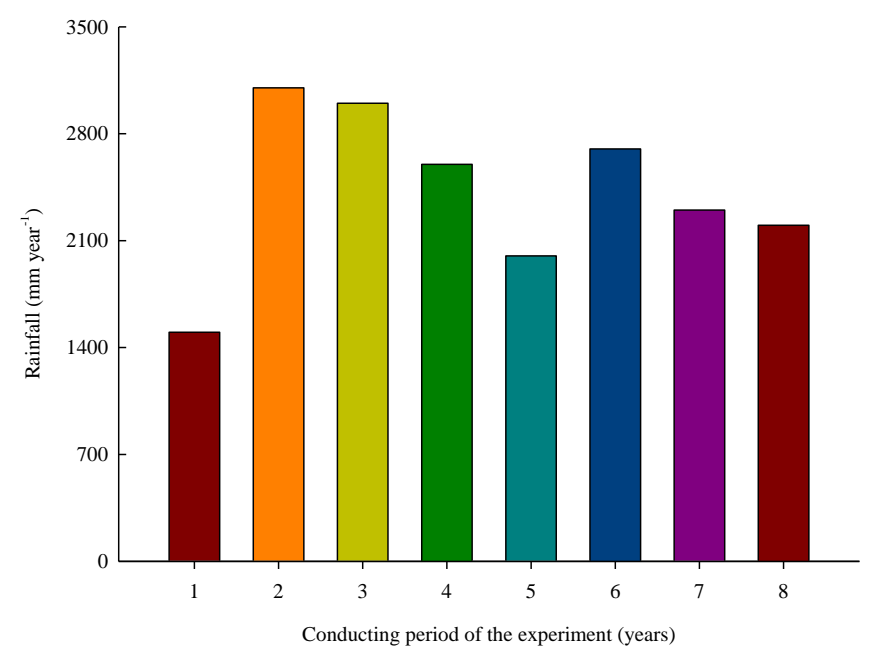

Figure 1. Annual rainfall occurred in the experimental area during the study period

The predominant soil in the region is the Yellow Oxisol, alic, leached and of low natural chemical fertility (Rodrigues et al., 2005). A granulometric analysis of the soil of the experiment area was performed; $671.4 \mathrm{~g} \mathrm{~kg}^{-1}$ of sand, $88.6 \mathrm{~g} \mathrm{~kg}^{-1}$ of silt and $238.6 \mathrm{~g} \mathrm{~kg}^{-1}$ of clay (sandy free texture). Also, chemical analyses of the soil $(0.0-0.3 \mathrm{~m})$ of the study area (Table 1) were performed. Both the particle size analysis and the soil chemical analyses were performed in the soil laboratory of Embrapa Amazônia Oriental.

Table 1. Chemical analysis of the soil $(0.0-0.3 \mathrm{~m})$ of the experimental area as a function of the age of the oil palm plantations (Viégas et al., 2018)

\begin{tabular}{|c|c|c|c|c|c|c|c|c|c|c|}
\hline \multirow{2}{*}{$\begin{array}{l}\text { Age of planting } \\
\text { Palm (years) }\end{array}$} & \multirow{2}{*}{$\frac{\mathrm{SOM}^{*}}{\mathrm{~g} \mathrm{~kg}^{-1}}$} & \multirow{2}{*}{$\begin{array}{c}\mathrm{pH} \\
\left(\mathrm{CaCl}_{2}\right)\end{array}$} & $\mathrm{P}^{* *}$ & $\mathrm{~K}^{+* *}$ & $\mathrm{Ca}^{2+* *}$ & $\mathrm{Mg}^{2+* *}$ & $\mathrm{Al}^{3+}$ & $\mathrm{H}+\mathrm{Al}^{* * *}$ & SB & \multirow{2}{*}{$\frac{\mathrm{V}}{\%}$} \\
\hline & & & \multicolumn{2}{|c|}{$\mathrm{mg} \mathrm{dm}{ }^{-3}$} & \multicolumn{5}{|c|}{---------- $\mathrm{cmol}_{\mathrm{c}} \mathrm{dm}^{-3}$} & \\
\hline 2 & 16.0 & 4.3 & 4.0 & 27.4 & 0.7 & 0.4 & 0.4 & 3.4 & 11.7 & 24 \\
\hline 3 & 23.0 & 4.4 & 6.0 & 23.5 & 0.7 & 0.2 & 0.3 & 2.8 & 9.6 & 24 \\
\hline 4 & 15.0 & 4.1 & 5.0 & 19.6 & 0.9 & 0.2 & 0.3 & 3.1 & 11.5 & 26 \\
\hline 5 & 19.0 & 4.0 & 6.0 & 27.4 & 0.8 & 0.3 & 0.5 & 3.8 & 11.7 & 22 \\
\hline 6 & 20.0 & 4.0 & 6.0 & 19.6 & 0.7 & 0.3 & 0.8 & 3.4 & 10.5 & 22 \\
\hline 7 & 21.0 & 4.3 & 6.0 & 19.6 & 0.7 & 0.3 & 0.4 & 2.6 & 10.5 & 27 \\
\hline 8 & 18.0 & 4.0 & 8.0 & 23.5 & 0.6 & 0.3 & 0.6 & 3.4 & 9.6 & 20 \\
\hline
\end{tabular}

Note. * Colorimetric method; ** Extracted with ion exchange resin; ***. SMP method; $\mathrm{Al}^{3+}$ extraction with $\mathrm{KCl} 1 \mathrm{~mol} \mathrm{~L}^{-1}$. SOM: soil organic matter, SB: Sum of the bases, V: Base saturation.

The experimental design used was completely randomized, with four replications, and seven treatments: oil palm plantings from the second to the eighth year of age. Tropical kudzu 
sowing was performed in the preparation of the oil palm field area, to sowing with $1 \mathrm{~kg} \mathrm{ha}^{-1}$ of uninoculated seeds. The spacing used in the planting of the oil palm was of an equilateral triangle of nine meters in quincuncial ( $9 \mathrm{~m}$ between plants and $7.80 \mathrm{~m}$ between rows) for a total of 143 plants ha ${ }^{-1}$.

Plant responses to treatments were evaluated based on the accumulation of macronutrients from the living, dead and total cover of tropical kudzu. The sampling was carried out between the lines of the oil palm plants by means of samples of the entire aerial part of the plants of living cover (green) and dead, using a wooden square of $0.5 \times 0.5 \mathrm{~m}\left(0.25 \mathrm{~m}^{2}\right)$, all samplings in the seven treatments were carried out in the same period. The green and dead samples of tropical kudzu were cleaned with distilled water, packed in paper bags, and dried in a greenhouse $\left(70{ }^{\circ} \mathrm{C}\right)$. After the determination of the dry matter of the samples, the plant material was grinding in a Wiley mill and, finally, the analyses of macronutrient concentrations (N, P, K, Ca, Mg and S). These were conducted in the soil and plant analysis laboratory of Embrapa Eastern Amazon, following the methodology of Carmo et al. (2000). Nutrients were extracted by sulfuric $(\mathrm{N})$ and nitroperchloric (P, K, Ca, Mg and S) digestion methods and subsequently determined by semi-micro Kjeldahl $(\mathrm{N})$, vanadate yellow spectrometry $(\mathrm{P})$, flame photometry $(\mathrm{K})$, atomic absorption spectrophotometry $(\mathrm{Ca}$ and $\mathrm{Mg}$ ) and turbidimetry $(\mathrm{S})$ methods.

The accumulation of macronutrients was obtained through the product of nutrient concentrations and the dry matter of the aerial part of the living and dead cover of tropical kudzu. The total accumulation of each nutrient was obtained by the sum of the accumulation in the living cover and in the dead cover. To extrapolate the dry matter production values of tropical kudzu to hectare, the clean areas around the oil palm (crowning) plants were subtracted, considering the radius of the crowning areas of $1.5 \mathrm{~m}$ in the first and second year, $2 \mathrm{~m}$ in the third year and $2.5 \mathrm{~m}$ in the fourth to eighth year of age of the plants.

Variance analysis $(\mathrm{p}<0.05)$ was performed, and the data were adjusted to regression models according to the age of the oil palm plants using the Agroestast software (Barbosa and Maldonato Junior, 2015).

\section{Results and Discussion}

$\mathrm{N}$ accumulations in the living, dead and total cover of tropical kudzu decreased as a function of the age of the oil palm plantations (Figure 2a). This decrease in $\mathrm{N}$ accumulation is due to lower dry matter production of tropical kudzu plants due to the increase in the planting age of oil palm (Viégas et al., 2018). In older oil palm plantations there is greater competition, mainly for light, causing greater shading from plants and lower dry matter production of tropical kudzu, with consequent lower accumulation of nutrients. Luna-Orea et al. (1996) also found that $\mathrm{N}$ accumulation in living tropical kudzu plants decreases as a function of time; obtaining $140 \mathrm{~kg} \mathrm{ha}^{-1}$ of $\mathrm{N}$ in plants at the first month of age and $117 \mathrm{~kg} \mathrm{ha}^{-1}$ of $\mathrm{N}$ in plants at the thirty-second month of age. 
Table 2. Summary of the analysis of variance (coefficient of variance $-\mathrm{CV}$, mean square and F test) of the variables evaluated (Nutrients accumulation)

\begin{tabular}{|c|c|c|c|c|}
\hline Accumulation & Plant Cover & CV (\%) & $\begin{array}{l}\text { Medium } \\
\text { Square }\end{array}$ & F test \\
\hline & Living & 10.18 & 6701.19 & $282.52 * *$ \\
\hline \multirow[t]{3}{*}{$\mathrm{N}$} & Dead & 10.51 & 55060.39 & $300.64 * *$ \\
\hline & Total & 9.38 & 99168.58 & $361.38 * *$ \\
\hline & Living & 11.36 & 17.89 & $202.24 * *$ \\
\hline \multirow[t]{3}{*}{$\mathrm{P}$} & Dead & 32.38 & 82.34 & $28.3 * *$ \\
\hline & Total & 22.67 & 172.84 & $54.09 * *$ \\
\hline & Living & 8.50 & 6313.36 & $793.42 * *$ \\
\hline \multirow[t]{3}{*}{$\mathrm{K}$} & Dead & 18.13 & 852.83 & $118.42 * *$ \\
\hline & Total & 5.18 & 11680.30 & $1887.53^{* *}$ \\
\hline & Living & 8.89 & 2359.32 & $384.54 * *$ \\
\hline \multirow[t]{3}{*}{$\mathrm{Ca}$} & Dead & 19.13 & 76715.91 & $94.01 * *$ \\
\hline & Total & 16.32 & 104951.56 & $125.51 * *$ \\
\hline & Living & 10.02 & 42.34 & $236.86^{* *}$ \\
\hline \multirow[t]{3}{*}{$\mathrm{Mg}$} & Dead & 19.34 & 914.28 & $93.94 * *$ \\
\hline & Total & 15.64 & 1335.86 & $131.85^{* *}$ \\
\hline & Living & 20.48 & 3.91 & $73.48 * *$ \\
\hline \multirow[t]{2}{*}{$\mathrm{S}$} & Dead & 51.05 & 76.47 & $9.28 * *$ \\
\hline & Total & 41.95 & 107.14 & $13.36^{* *}$ \\
\hline
\end{tabular}

Note. ${ }^{* *}, *$, NS - significant at $1 \%$, at $5 \%$ and no significant, respectively. 
The maximum accumulation of $\mathrm{N}$ in the living cover of tropical kudzu was observed at two years $\left(125 \mathrm{~kg} \mathrm{ha}^{-1}\right)$ and, in the dead cover, also at two years $\left(330 \mathrm{~kg} \mathrm{ha}^{-1}\right)$ totaling the accumulation of $455 \mathrm{~kg} \mathrm{ha}^{-1}$ of $\mathrm{N}$ (Figure $2 \mathrm{a}$ ), corresponding to $1,011 \mathrm{~kg} \mathrm{ha}^{-1}$ of urea (45\% of $\mathrm{N})$. Thus, there was a decrease in $\mathrm{N}$ accumulation in relation to the age of oil palm, with lower accumulation in the eighth year in the living cover $\left(7.2 \mathrm{~kg} \mathrm{ha}^{-1}\right)$ and in the dead cover (23.5 $\left.\mathrm{kg} \mathrm{ha}^{-1}\right)$, performing the total cycling of $30.7 \mathrm{~kg} \mathrm{ha}^{-1}$ of $\mathrm{N}$, corresponding to only 68.2 $\mathrm{kg} \mathrm{ha}^{-1}$ of urea, being 14.8 times lower than obtained in the second year. The lower accumulation of $\mathrm{N}$ in tropical kudzu in intercropping with older oil palm is expected, since when the root system of oil palm grows between the lines, competition for nutrients leads to a gradual decline in the yield of cover crops (Agamuthu and Broughton, 1984). The decrease in $\mathrm{N}$ accumulation in the dead cover of kudzu plants as a function of the age of oil palm plants observed in the present study may also be related to the increase in $\mathrm{N}$ demand for oil palm plants, since it increases from 86 to $113 \mathrm{~kg} \mathrm{ha}^{-1}$ of $\mathrm{N}$ from the fourth to the fifth year of crop plantations (Franzini et al., 2020), considering 143 plants ha $^{-1}$ and a productivity of $17 \mathrm{t} \mathrm{ha}^{-1}$.

Espindola et al. (2006), evaluating the dead cover of tropical kudzu in banana plantations, verified accumulation of $126 \mathrm{~kg} \mathrm{ha}^{-1}$ of $\mathrm{N}$. In coffee plantations, research conducted with cover crops concluded that biological fixation is responsible for $80 \%$ of $\mathrm{N}$ accumulation in legumes (Partelli et al., 2011). In Europe, the evaluation of nineteen legume species indicated that all plants were able to perform $\mathrm{N}$ fixation above $100 \mathrm{~kg} \mathrm{ha}^{-1}$ (Buchi et al., 2015). In this sense, it is verified that the use of legumes such as tropical kudzu contributes to an increase in the supply of $\mathrm{N}$ in the agroecosystem, increasing its availability for oil palm and promoting savings in the use of mineral $\mathrm{N}$ fertilizers.

In oil palm plantation where the legume Pueraria phaseoloides L. is used as a soil cover plant, $\mathrm{N}$ fertilization is dispensed from the first year of planting (Viégas and Botelho, 2007). There was no positive response to $\mathrm{N}$ fertilization (urea), compared to the absence of $\mathrm{N}$ supply, with Pueraria phaseoloides as soil cover (Viégas et al., 2019). In cultivation of coconut plants, is suggested the reduction of mineral $\mathrm{N}$ fertilization when in intercropping with Pueraria phaseoloides L. (Lins and Viégas, 2020).

For the average productivity of the oil palm in Pará (17 t ha ${ }^{-1}$; Homma and Rebello, 2020), the current recommendation (Franzini et al., 2020) is $113 \mathrm{~kg} \mathrm{ha}^{-1}$ of $\mathrm{N}$, a quantity lower than the $\mathrm{N}$ cycled $\left(128 \mathrm{~kg} \mathrm{ha}^{-1}\right)$ in the dead cover of tropical kudzu in the average of eight years. In the living cover of kudzu, the average amount of cycled $\mathrm{N}$ represents $42 \%\left(47.9 \mathrm{~kg} \mathrm{ha}^{-1}\right)$ of the demand for this nutrient from oil palm (Figure 2a). 

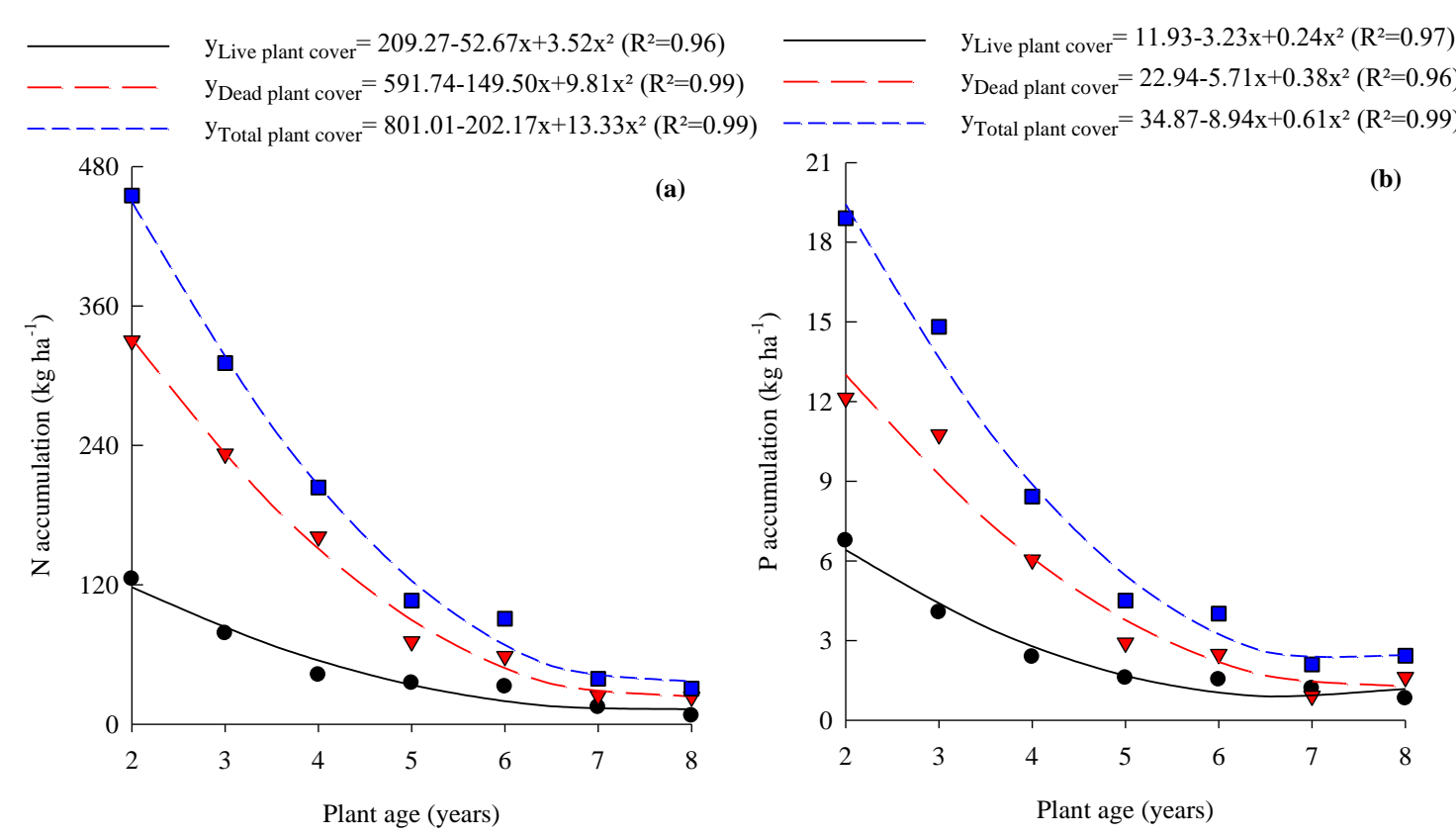

Figure 2. Accumulation of $\mathrm{N}$ (a) and $\mathrm{P}$ (b) in living, dead, and total cover of tropical kudzu as a function of the age of the oil palm plantations

For $\mathrm{P}$ accumulations, there was a decrease in their values in the living, dead and total cover of tropical kudzu as a function of the age of the oil palm plantations (Figure 2b). This fact is due to the decrease in dry matter production of tropical kudzu plants intercropped with older oil palms (Viégas et al., 2018), since the concentration of $\mathrm{P}$ in this cover plant is higher at older ages of palm oil plantations (Peréz and Viégas, 1997). In a study conducted in the Bolivian Amazon, a decrease in $\mathrm{P}$ accumulation was observed due to the age of tropical kudzu; $13 \mathrm{~kg}$ $\mathrm{ha}^{-1}$ of $\mathrm{P}$ at the first month of age and $10 \mathrm{~kg} \mathrm{ha}^{-1}$ of $\mathrm{P}$ at the thirty-second month of plant age (Luna Orea et al., 1996). Espindola et al. (2006), evaluating the effect of dead cover of tropical kudzu in banana plantations, verified accumulation of 9.8 to $10.3 \mathrm{~kg} \mathrm{ha}^{-1}$ of P. Under the conditions of Pará State, the demand of oil palm is estimated at $38 \mathrm{~kg} \mathrm{ha}^{-1}$ of $\mathrm{P}$ in plantations with 143 plants ha ${ }^{-1}$ and productivity of $17 \mathrm{tha}^{-1}$ of bunches (Franzini et al., 2020). Thus, there is the potential of tropical kudzu to contribute to the supply of the nutrient; on the average of the eight years evaluated up to $7 \%$ (2.6 kg ha-1 of P) in living cover and $14 \%$ (5.3 $\mathrm{kg} \mathrm{ha}^{-1}$ of $\left.\mathrm{P}\right)$ in dead cover, totaling $21 \%\left(7.9 \mathrm{~kg} \mathrm{ha}^{-1}\right.$ of $\left.\mathrm{P}\right)$. On average for eight years, the $7.9 \mathrm{~kg} \mathrm{ha}^{-1}$ of $\mathrm{P}$ is equivalent to $41 \mathrm{~kg} \mathrm{ha}^{-1}$ of triple superphosphate $\left(44 \%\right.$ of $\left.\mathrm{P}_{2} \mathrm{O}_{5}\right)$.

For the accumulations of $\mathrm{K}$ in the living, dead and total cover of tropical kudzu, there were quadratic responses, decreasing according to the age of the oil palm plantations (Figure $3 \mathrm{a}$ ). In a research conducted with tropical kudzu also indicated a decrease in $\mathrm{K}$ accumulation as a function of time; in the first month of age of the plants the accumulation of K was $74 \mathrm{~kg} \mathrm{ha}^{-1}$ and at the twenty-second month of age it was $70 \mathrm{~kg} \mathrm{ha}^{-1}$ (Luna Orea et al., 1996). On the other hand, a research carried out with dead cover of tropical kudzu in banana cultivation verified the accumulation of 44 to $47 \mathrm{~kg} \mathrm{ha}^{-1}$ of $\mathrm{K}$ (Espindola et al., 2006). In the current research, in the living cover, the maximum cycling of $\mathrm{K}\left(116.4 \mathrm{~kg} \mathrm{ha}^{-1}\right)$ occurred at 2 years of planting and, the minimum $\left(5.5 \mathrm{~kg} \mathrm{ha}^{-1}\right)$, at the eighth year (Figure $\left.3 \mathrm{a}\right)$. In this sense, the 
potential of tropical kudzu is verified in supplying $\mathrm{K}$ to oil palm plants, contributing to the sustainability of the consortium.

A study evaluating nutrient cycling in tropical kudzu dead cover residue in rainy season indicated that $\mathrm{K}$ is the fastest-released nutrient (Espindola et al., 2006). This fact justifies the lower accumulation of $\mathrm{K}$ in the dead cover of tropical kudzu in relation to the living cover, indicating the rapid release of the nutrient (Figure 3a). For an average yield of $17 \mathrm{tha}^{-1}$, the recommendation of $\mathrm{K}$ fertilization for oil palm in Pará is $169 \mathrm{~kg} \mathrm{ha}^{-1}$ (Franzini et al., 2020). Thus, the supply of $\mathrm{K}$ due to its cycling by tropical kudzu can contribute to the reduction of the applied level of the nutrient in mineral fertilizers. K cycling in tropical kudzu was $33.2 \mathrm{~kg}$ $\mathrm{ha}^{-1}$ in living cover, $13.4 \mathrm{~kg} \mathrm{ha}^{-1}$ in dead cover and $46.6 \mathrm{~kg} \mathrm{ha}^{-1}$ in total, indicating a decrease of $27.6 \%$ in the application of $\mathrm{K}$ fertilizers. The low cycled values of $\mathrm{K}$ verified in the tropical kudzu of the present study are the result of the low absorption of the nutrient by the cover plant (Peréz and Viégas, 1997) due to its low availability in the soil of oil palm plantations (Table 1; Brasil and Cravo, 2020).

$\mathrm{Ca}$ accumulations in the living, dead and total cover of tropical kudzu decreased with the age of the oil palm plantations (Figure 3b). A decrease in Ca accumulation in tropical kudzu was also observed in the Bolivian Amazon from 14 to $11 \mathrm{~kg} \mathrm{ha}^{-1}$ from first to the thirty-second month of plant age (Luna Orea et al., 1996). Research with dead cover of tropical kudzu indicated, in the dry period, accumulation of $38 \mathrm{~kg} \mathrm{ha}^{-1}$ of Ca and, in rainy season, of $63 \mathrm{~kg}$ ha $^{-1}$ of Ca (Espindola et al., 2006).

In the present study, the accumulation of $\mathrm{Ca}$ in the living cover ranged from 3.8 to $70.6 \mathrm{~kg}$ $\mathrm{ha}^{-1}$, providing an average cycling of $27.9 \mathrm{~kg} \mathrm{ha}^{-1}$ of $\mathrm{Ca}$ (Figure $3 \mathrm{~b}$ ). Oil palm plantations, with productivity of $17 \mathrm{t} \mathrm{ha}^{-1}$ and density of 143 plants ha $^{-1}$, present a demand of $68 \mathrm{~kg} \mathrm{ha}^{-1}$ of Ca (Franzini et al., 2020), indicating that tropical kudzu can supply $41 \%$ of the nutrient. In this sense, tropical kudzu can contribute to increased nutrient availability, since, according to Matos et al. (2016), Ca is among the nutrients with the highest frequency of deficiency in oil palm plantations in Pará. Espibndola et al. (2006) report that $\mathrm{Ca}$ is the nutrient with slower release in tropical kudzu. 

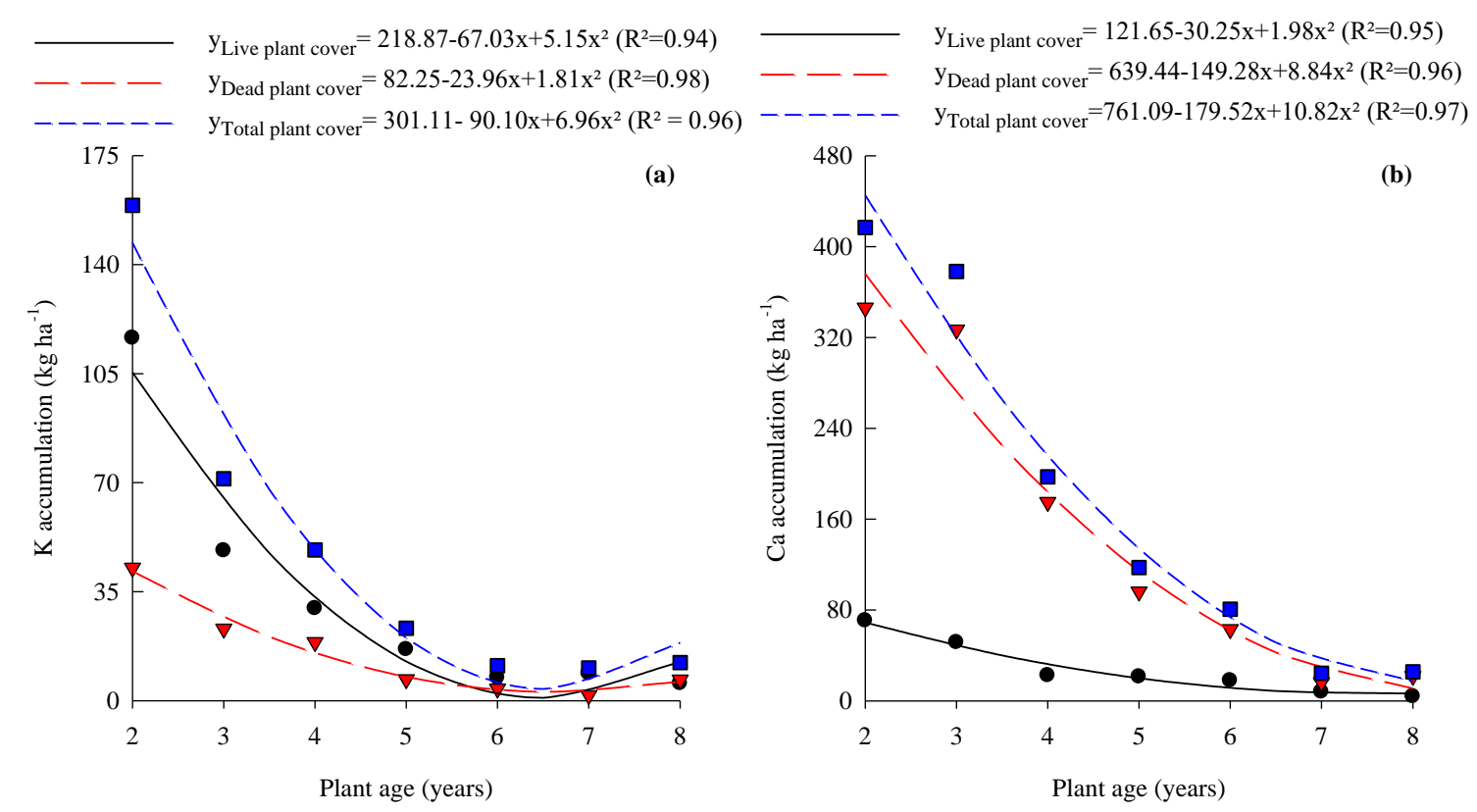

Figure 3. Accumulation of $\mathrm{K}$ (a) and $\mathrm{Ca}$ (b) in living, dead, and total cover of tropical kudzu as a function of the age of the oil palm plantations

The accumulation of $\mathrm{Mg}$ in the living, dead and total cover of tropical kudzu also decreased as a function of the age of the oil palm (Figure 4a). A similar result was observed by Luna Orea et al. (1996) in living cover of tropical kudzu; $\mathrm{Mg}$ accumulation decreased from $8 \mathrm{~kg}$ $\mathrm{ha}^{-1}$ in the first month to $6 \mathrm{~kg} \mathrm{ha}^{-1}$ at thirty-second month of plant age. The use of dead cover of tropical kudzu in banana plantation indicated higher accumulation of $\mathrm{Mg}\left(25 \mathrm{~kg} \mathrm{ha}^{-1}\right)$ in rainy season compared to dry period $\left(15 \mathrm{~kg} \mathrm{ha}^{-1}\right)$ (Espindola et al., 2006). The data of the present study indicate an average cycling of 4.2 and $16.1 \mathrm{~kg} \mathrm{ha}^{-1}$ of $\mathrm{Mg}$ in living and dead cover, respectively, totaling $20.3 \mathrm{~kg} \mathrm{ha}^{-1}$ of cycled $\mathrm{Mg}$ (Figure 4a). The recommendation of $\mathrm{Mg}$ fertilization for a productivity of $17 \mathrm{t} \mathrm{ha}^{-1}$ of the oil palm in Pará is $34 \mathrm{~kg} \mathrm{ha}^{-1}$ (Franzini et $a l ., 2020)$. There is an indication of positive response in the production of oil palm plants to $\mathrm{Mg}$ fertilization in the region (Oliveira et al., 2019).

For S accumulation in the living, dead and total covers of tropical kudzu, there was also a decrease in the values as a function of the age of the oil palm (Figure 4b). Research evaluating other legumes as cover plants found that the crotalaria accumulated $13.8 \mathrm{~kg} \mathrm{ha}^{-1}$ of S (Silva et al., 2010). The decrease in S accumulation in tropical kudzu as a function of oil palm age may also be related to the export of the nutrient by bunches. Franzini et al. (2020) estimate that there is export of $8.5 \mathrm{~kg} \mathrm{ha}^{-1}$ of $\mathrm{S}$ in planting with $17 \mathrm{t} \mathrm{ha}^{-1}$ of bunches of fresh fruits. Thus, for this productivity, the same authors recommend applying $20 \mathrm{~kg} \mathrm{ha}^{-1}$ of $\mathrm{S}$ in oil palm plantation. The total cycling of $S$ in the tropical kudzu ranged from 1.2 to $13.2 \mathrm{~kg} \mathrm{ha}^{-1}$ at the eighth and second year, respectively (Figure $4 \mathrm{~b}$ ). Thus, there is the contribution in the nutrition of the oil palm in cultivation intercropped with tropical kudzu by the cycling of $S$. This fact becomes relevant since the $S$ was pointed out as one of the nutrients with the highest incidence of deficiency in the planting of oil palm in Pará (Matos et al., 2019). 


\section{Macrothink}

It is note point that lower $\mathrm{S}$ cycled values by tropical kudzu are also due to low concentrations of the nutrient in the tissue of these plants (Peréz and Viégas, 1997), due to the low concentration of soil organic matter (Table 1), the main source of S in the soil (Vitti et al., 2018). The high rate of mineralization and the high leaching of $S$ favors the occurrence of nutrient deficiency in the planting of oil palm in Pará (Matos et al., 2016), factors favored by the climate of the current study (Figure 1). Thus, it is observed that for all macronutrients cycled by kudzu plants there is a decrease in their accumulations according to the increase in the age of oil palm plantations. The kudzu is a heliophilous legume that needs sun exposure with low luminous composition point, which when shaded by palms trees over the years reduces the accumulation of macronutrients.
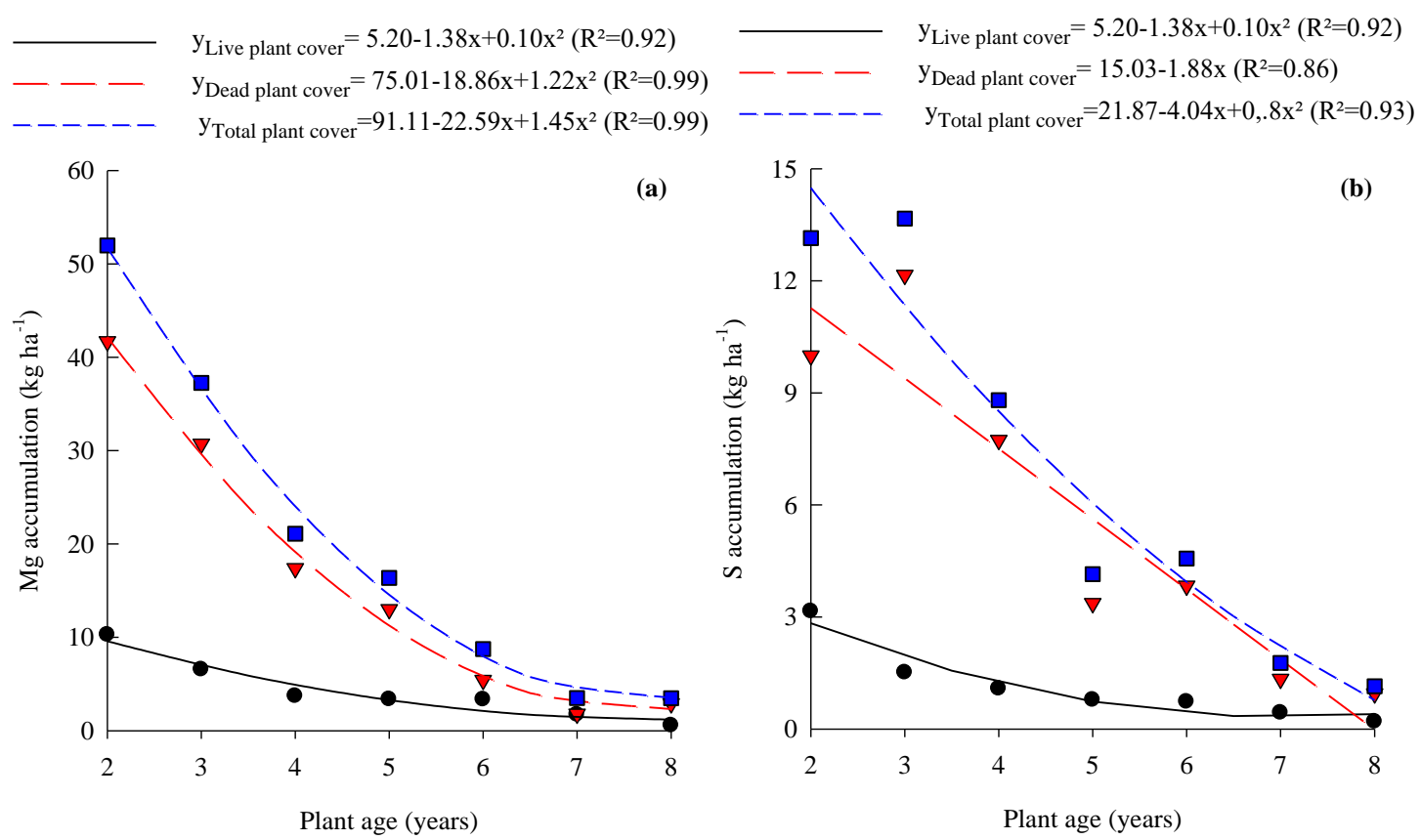

(a)

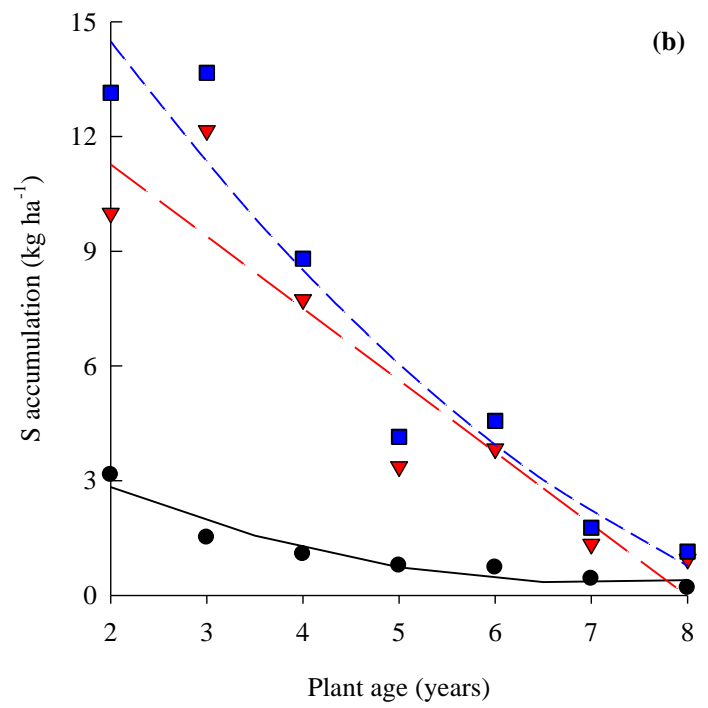

Figure 4. Accumulation of $\mathrm{Mg}$ (a) and S (b) in living, dead, and total cover of tropical kudzu as a function of the age of the oil palm plantations

\section{Conclusions}

- The accumulation of macronutrients in cover of tropical kudzu decreases as a function of the age of the oil palm, being in the order: $\mathrm{N}>\mathrm{K}>\mathrm{Ca}>\mathrm{Mg}>\mathrm{P}>\mathrm{S}$ in the living, $\mathrm{Ca}>\mathrm{N}>\mathrm{Mg}>\mathrm{K}>\mathrm{S}>\mathrm{P}$ in the dead and $\mathrm{Ca}>\mathrm{N}>\mathrm{K}>\mathrm{Mg}>\mathrm{P}>\mathrm{S}$ in total.

- Pueraria phaseoloides L. contributes to macronutrients cycling and become an option of sustainable management to cultivation of palm oil trees, with potential reduction in the use of mineral fertilizers. However, the macronutrients cycling by kudzu plants decreases with their ages.

\section{References}

Agamuthu, P., \& Broughton, W. J. (1985). Nutrient cycling within the developing oil palm legume ecosystem. Agriculture, Ecosystems and Environment, 13, 111-123. 
https://doi.org/10.1016/0167-8809(85)90054-4

Alvarez, V. H., Novais, R. F., Barros, N. F., Cantarutti, R. B., \& Lopes, A. S. (1999). Interpretação dos resultados das análises de solos. In A. C. Ribeiro, P. T. G. Guimarães, and V. H. Alvarez (eds.), Recomendações para o uso de corretivos e fertilizantes em Minas Gerais (p. 25-32; 5. Ed). Viçosa: Comissão de Fertilidade do Solo do Estado de Minas Gerais.

Baligar, V. C., Fageria, N. K.; \& He, Z. L. (2001). Nutrient use efficiency in plants. Communications in Soil Science and Plant Analysis, 32, 921-950. https://doi.org/10.1081/CSS-100104098

Barbosa, J. C., \& Maldonado Junior, W. (2015). AgroEstat - sistema para análises estatísticas de ensaios agronômicos. Jaboticabal: FCAV/UNESP.

Brasil, E. C., \& Cravo, M. S. (2020). Interpretação dos resultados da análise do solo. In E. C. Brasil, M. S. Cravo, and I. J. de M. Viégas (Eds.), Recomendações de calagem e adubação para o estado do Pará (p. 61-64; 2. Ed.). Brasília: Embrapa.

Buchi, L., Gebhard, G. A., liebisch, F., Sinaj, S., Ramseier, \& Charles, R. (2015). Accumulation of biologically fixed nitrogen by legumes cultivated as cover crops in Switzerland. Plant Soil, 393, 163-175. https://doi.org/10.1007/s11104-015-2476-7

Cantarella, H. (2007). Nitrogênio. In R. F. Novais, V. H. Alvarez, N. F. Barros, R. L. F. Fontes, R. B. Canturutti, J. C. L. Neves (Ed.), Fertilidade do Solo (p. 375-470). Viçosa: Sociedade Brasileira de Ciência do Solo.

Carmo, C. A. F. S., Araújo, W. S., Bernardi, A. C. C., \& Saldanha, M. F. C. (2000). Métodos de análise de tecidos vegetais utilizados na Embrapa Solos. Rio de Janeiro: Embrapa Solos.

Espindola, J. A. A., Guerra, J. G. M., Almeida, D. L., Teixeira, M. G., \& Urquiaga, S. (2006). Decomposição e liberação de nutrientes acumulados em leguminosas herbáceas perenes consorciadas com bananeira. Revista Brasileira de Ciência do Solo, 30, 321-328. https://doi.org/10.1590/S0100-06832006000200012

Fageria, N. K., Baligar, V. C., \& Li, Y. C. (2014a). Nutrient uptake and use efficiency by tropical legume cover crops at varying $\mathrm{pH}$ of an oxisol. Journal of Plant Nutrition, 37, 294-311. https://doi.org/10.1080/01904167.2013.851695.

Fageria, N. K., Baligar, V. C., Moreira, A., \& Moraes, L. A. C. (2014b). Soil phosphorous influence on growth and nutrition of tropical legume cover crops in acidic soil. Communications in Soil Science and Plant Analysis, 44, 37-41. https://doi.org/10.1080/00103624.2013.847954

Favero, C., Jucksch, I., Costa, L. M., Alvarenga, R. C., \& Neves, J. C. L. (2000). Crescimento e acúmulo de nutrientes por plantas espontâneas e leguminosas utilizadas para adubação verde. Revista Brasileira de Ciência do Solo, 24, 171-177. https://doi.org/10.1590/S0100-06832000000100019

Franzini, V. I., Matos, G. S. B., Machado, D. N., Assunção, E. A., Viégas, I. J. de M., \& Botelho, S. M. (2020). Palma de óleo (Dendezeiro). In E. C. Brasil, M. S. Cravo, and I. J. de M. Viégas (Eds.), Recomendações de calagem e adubação para o estado do Pará (p. 279-282; 2. Ed.). Brasília: Embrapa.

Franzini, V. I., Souza, M. B., Gomes Junior, R. A., Silva, A. R. B., \& Rodrigues, E. C. F. (2017). Fertilidade do solo, nutrição e desenvolvimento vegetativo da palma de óleo 
consorciada com culturas alimentares. Belém: Embrapa Amazônia Oriental.

Homma, A. K. O., \& Rebello, F. K. (2020). Aspectos econômicos da adubação e da calagem na Amazônia. In E. C. Brasil, M. S. Cravo, and I. J. de M. Viégas (Eds.), Recomendações de calagem e adubação para o estado do Pará (p. 185-204; 2. Ed.). Brasília: Embrapa.

Hutasoit, R., Juniar, S., Tarigan, A., \& Ratih, D. H. (2017). Evaluation of Four Pasture Legumes Species as Forages and Cover Crops in Oil Palm Plantation. Indonesian Journal of Animal and veterinary sciences, 22, 124-134. https://doi.org/10.14334/jitv.v22i3.1801.

IBGE (2017). Censo Agropecuário. Available in: https://www.ibge.gov.br/estatisticas /economicas/agricultura-e-pecuaria/21814-2017-censo-agropecuario.html?=\&t=o-que-e.

Accessed in 15 dez. 2020.

Lins, P. M. P., \& Viégas, I. de J. M. (2020). Coqueiro. In E. C. Brasil, M. S. Cravo, and I. J. de M. Viégas (Eds.). Recomendações de calagem e adubação para o estado do Pará (p. 347-350; 2. Ed.). Brasília: Embrapa.

Luna Orea, P., Wagnner, M. G., \& Gumpertz, M. L. (1996). Decomposition and Nutrient Release Dynamics of Two Tropical Legume Cover Crops. Agronomy Journal, 88, 758-764. https://doi.org/10.2134/agronj1996.00021962008800050013x

Matos, G. S. B., Fernandes, A. R., \& Wadt, P. G. S. (2016). Níveis críticos e faixas de suficiência de nutrientes derivados de métodos de avaliação do estado nutricional da palma-de-óleo. Pesquisa Agropecuária Brasileira, 51, 1557-1567. https://doi.org/10.1590/s0100-204x2016000900055

Matos, G. S. B., Rodrigues, G. R., GAMA, M. A. P., Galvão, J. R., Viégas, I. de J. M., \& Macedo Neto, A. A. L. (2019). Compositional nutrient diagnosis in two oil palm genetic materials. Revista Ibero Americana de Ciências Ambientais, 10, 1-5. https://doi.org/10.6008/CBPC2179-6858.2019.006.0001

Oliveira, S. S., Saldanha, E. C. M., Santa Brígida, M. R. S., Cordeiro, N. K., Rocha, H. G. A., Araújo, J. L. S., Almeida, G. M., \& Lobato, W. T. S. (2019). Effect of Different Doses of Magnesium Sulphate Monohydrate on Productivity of Oil Palm. Journal of Experimental Agriculture International, 29, 1-9, 2019. https://doi.org/10.9734/JEAI/2019/44818

Partelli, F. L., Vieira, H. D., Ferreira, E. P. B., Viana, A. P., Espinhola, J. A. A., Urquiaga, S., \& Boddey, R. M. (2011). Biologic dinitrogen fixation and nutrient cycling in cover crops and their effect on organic Conilon coffee. Semina: Ciências Agrárias, 32, 995-1006. https://doi.org/10.5433/1679-0359.2011v32n3p995

Peréz, N. L. P., \& Viégas, I. J. M. (1997). Matéria seca e concentração de macronutrientes em Pueraria Phaseoloides L., com dois a oito anos de idade, nas condições de plantações industriais de dendezeiro em Latossolo Amarelo, Tailândia - Pará. Boletim da Faculdade de Ciências Agrárias do Pará, 28, 149-168.

Pissinati, A., Moreira, A., \& Santoro, P. H. (2018). Yield components and nutrients content in summer cover plants used in crop rotation in no-tillage system. Communications in Soil Science and Plant Analysis, 49, 1604-1616. https://doi.org/10.1080/00103624.2018.1474899

Rodrigues, M. R, Amblard, P., Silva, E. B., Macedo, J. L., Cunha, R. N., \& Tavares, A. M. (2002). Avaliação do Estado Nutricional do dendezeiro: análise foliar. Circular Técnica, 11. Manaus: Embrapa Amazônia Ocidental. 
Rodrigues, T. E., Silva, J. M. L., Silva, B. N. R., Valente, M., Gama, J., Santos, E. S., Rollim, P. A. M.; \& Ponte, F. C. (2005). Caracterização e classificação dos solos do município de Tailândia, estado do Pará. Belém: Embrapa Amazônia Oriental.

Silva, A. G., Crusciol, C. A. C., Soratto, R. P., Costa, C. H. M., \& Ferrari Neto, J. (2010). Produção de fitomassa e acúmulo de nutrientes por plantas de cobertura e cultivo da mamona em sucessão no sistema plantio direto. Ciência Rural, 40, 2092-2098. https://doi.org/10.1590/S0103-84782010001000007

Viégas, I. de J. M., \& Botelho, S. M. (2007). Dendezeiro. In M. S. Cravo, I. de J. M. Viégas, and E. C. Brasil (Eds.), Recomendações de Adubação e Calagem para o Estado do Pará (p. 169-172). Belém: Embrapa Amazônia Oriental.

Viégas, I. de J. M., Galvão, J. R., Santos, C. R. C., Silva, D. A. S., Sodré, D. C., \& Freitas, J. M. N. (2018). Micronutrients content in Pueraria phaseoloides L. on soils under oil palm plantations in Tailândia, state of Pará. Bioscience Journal, 34, 59-66. https://doi.org/10.14393/BJ-v34n1a2018-36398

Viégas, I. de J. M., Pimentel, M. J. O., Galvão, J. R., Silva, D. A. S., Ferreira, E. V. O., Silva Junior, M. L., Yakuwa, T. K. M., \& Lima, S. K. S. (2019). Adubação mineral na fase produtiva da palma óleo (Elaeis guineenses Jacq) cultivado na região Amazônica. Revista Ibero-Americana de Ciências Ambientais, 10, 274-286. https://doi.org/10.6008/CBPC2179-6858.2019.006.0024

Vitti, G. C., Otto, R., Savieto, J., Lima, E., \& Santos, L. A. (2018). Enxofre. In M. S. Fernandes, S. R. Souza, and L. A. Santos (Eds.), Nutrição Mineral de Plantas (p. 465-490). Viçosa: Sociedade Brasileira de Ciência do Solo.

\section{Copyright Disclaimer}

Copyright for this article is retained by the author(s), with first publication rights granted to the journal.

This is an open-access article distributed under the terms and conditions of the Creative Commons Attribution license (http://creativecommons.org/licenses/by/4.0/). 